\title{
The Role of Anthropology in Retailing: An Autoethnographic Case Study
}

\author{
David E. McClendon Sr. \\ McClendon Enterprises
}

As demonstrated by examples from my family business, the techniques of anthropology have a significant role in retailing. The research methods of anthropology facilitate qualitative observations, formal or informal interviews, and dialogues. Accordingly, the "life story approach" can be particularly useful. Many of these techniques can be usefully applied by lay people with minimal formal training in the field. In this article, by using life story and autoethnographic approaches, I share several personal stories with the readers of how anthropology was used in the different businesses in which my family and I were involved. Those who share the same practical business experiences as I, may learn how daily business operations can be studied, developed and managed. As a business owner, I recognize the importance of anthropological methods which benefit the business community through practical application.

\section{INTRODUCTION}

Anthropology studies people, their behavior, and cultures using methods such as participant observation, informal interviews, dialogues with informants, and the analysis of "life stories." Having one foot planted in social analysis and the other within the strategic sciences, business anthropologists are emerging as cross disciplinary professionals who facilitate understanding options from a cross cultural perspective. Ideally, these professionals have training and expertise in the theoretical social sciences and within business, policy science, etc. (Jordan, 2003; Tian et al., 2010).

Some, like business anthropologist Dr. Gordon Bronitsky, employ their skills to manage their own businesses (Bronitsky, 2010). Others, like I, who have not been trained in anthropology, may also use anthropological principles in a strategic manner both consciously and unconsciously. Early on I became aware of some anthropological works on retail businesses, such as Why We Buy: The Science of Shopping by Dr. Paco Underhill (1999), and Experiential Retailing: Concepts and Strategies that Sell (Kim et al., 2007). The work done by Underhill and other scholars helped me realize that much of what I had observed during the day to day operations of the businesses could be used to improve customer service and profitability.

Family business has been a topic of study for applied anthropologists, and the life story approach is an effective research method that has been used by anthropologists to do 
ethnographic studies for many years (Jones, 2005; Poutziouris et al., 2006; Steward, 2003; Dossa, 1994). In addition, anthropologists have developed a new approach based on the researcher's own experiences termed as autoethnography (Chang, 2008). Autoethnographic study is the process of conducting and producing an ethnographic study through the understanding of self, others, and culture. It studies the role of the self in research, and the relationship of self to culture. There are a variety of techniques involved in autoethnographics for gathering data on the self, diaries, culture grams, recalling life stories and interviews with others.

In this autoethnographic study, I will use my own life experience and stories as a tool to explore perspectives and to arrive at a deeper understanding of others in the retail world. I will first share background information about my family business history, then how I gathered practical knowledge through family business history, my own life experiences and stories.

It is the goal of this article to use snippets of autoethnographic stories as well as stories that have been shared in the business world for decades in an attempt to put a little common sense into the field of business anthropology and put anthropological theories into business practice.

\section{BACKGROUND}

Several changes have taken place in retail since the time of small mom and pop stores (Kim et al., 2007; Underhill, 1999, 2010). In the days of the stores like those of my great-grandfather and grandfather self-service was virtually unheard of. In their day customers went into the store and handed the proprietor their shopping list. If a woman needed feminine protection she would write "brown bag" on the list. The proprietor would go to a shelf where the sanitary napkins were kept in brown bags so as not to offend customers. Whatever one wanted they were pretty much stuck with the brands and sizes the store carried. There was very little selection. If someone wanted a soft drink they got a Coke ${ }^{\circledR}$. Most stores in the rural South did not carry both Coke ${ }^{\circledR}$ and Pepsi ${ }^{\circledR}$ at that time. As far back as I know my family has been in retail. Many of my family's stories involve things that happened to my family while performing retail transactions.

My great-grandfather, Luther Jack McClendon, had a small general store in the Red Hill Community of Modoc, South Carolina. My father was born in the family home that was located just behind the store. Later my grandfather, Robert Bruce McClendon, Sr., opened a general store in Johnston, South Carolina. Sadly, my grandfather died at the age of 42 and my father took over the business. My father, Robert Bruce McClendon, Jr., was just a teenager at the time he tried to run the store. Due to the lack of cash-flow my father and his mother decided to close the store.

After that my father attended Newberry College in South Carolina on a football scholarship. He majored in business. This was the 1950s and most of the college boys there were well to do and were waiting on money from home so they could live it up. Meanwhile my father was playing on the football team, working at a drug store as a soda jerk and picking up odd jobs. He had a side business where he made arrangements with a local dry cleaner to receive a discount on dry cleaning. He would pick up clothes from people on campus and he would walk to the dry cleaners carrying the clothes. Often people who were paying him to pickup clothing would drive by him and honk and make fun of him. He would just laugh and say, "I am going to own you someday." While other boys were waiting on checks from home, my father was sending money back to his mother so she could feed herself and his brother and sister. After one year he decided this was too much so he joined the Air Force. He figured he could finish college and send money home at the same time. 
Later he went to work for National Cash Register Company (The N.C.R.). While working there he was always the number one or number two salesman in the company and, each year he was there, he would be a member of the coveted C.P.C. (Counter Points Club) which was for the best of the best in the company. My father was very proud of his successful business experience and always taught me that I should learn from him if I want to succeed in a retail business. He taught me about integrity, the one thing that good business person must learn. Integrity goes a long way. If you do not have integrity, sooner or later, your actions will come back to haunt you. If you do have integrity somewhere down the road it will help you out.

As a self employed businessman, my father had to study the needs of his customers and fill those needs. Consumer behavior would, come in to play but he had to first assess needs and find a creative way to fill it. Recalling stories and what I had observed over the years about my father's business operation, I realized that the anthropological approach in studying consumer behavior was employed by my father all the time though he might not have realized what he was doing at the time.

\section{BOWLING MAN}

My father always told me that it is important that we do business ethically. If we stick to business ethics, we might lose one or two profitable opportunities, but in the long run we would benefit from our ethical business conduct. He used to tell the story of a man who owned a large company of stores and was a prospect for buying cash registers. It turned out that the man had not been bowling in a while and really wanted to go bowling. My father agreed to take him bowling while they talked over a purchase. While they were bowling the man drank many beers. The man became a little drunk and signed the largest order my father had ever made. All my father had to do was mail that order and the man would be obligated to purchase the cash registers. He was faced with an ethical dilemma.

My father thought about it all that night. Early the next morning my father went to see the man at his office. He handed the man the contract signed the night before while his client had been drinking and told him that he was legally obligated to purchase the cash registers but that he, my father, thought that it would be much better if they tore up that contract and started over. The man was very happy and tore up the contract. He and my father then sat down and negotiated a much smaller order. My father lost on that sale but for the rest of the time my father was with National Cash Register he would get a purchase order in the mail for every single cash register ever purchased by that company and every paper product, ribbon and other accessory related to any product that National Cash Register offered that the store needed.

Several anthropologists have studied business ethics and revealed that unethical business conduct will destroy business reputation and eventually lead to bankruptcy (Jordan, 2003; Kim et al., 2007; Underhill, 1999, 2010). The Bowling Man story reflects my father's ethical values in his business operations. He upheld his values and let his client reconsider the deal. Although the new contract became a small order, my father's business benefited over time from his decision.

\section{MCCLENDON'S WESTERN AUTO}

My father decided to open his own business in the early 1970's after N.C.R. went from paying their salesmen straight commission to paying them a salary of about $\$ 20 \mathrm{~K}$ per year. What this meant was that people like my father, who was making over $\$ 60 \mathrm{k}$ per year as successful 
salesmen would take a hefty cut in pay. We then went in search of a town to open a Western Auto car sales company and we landed in Iva, South Carolina. He used anthropological methods to decide what type of store and where to build. He researched business trends and demographic data along with observation and analysis to make rational decisions.

From day one at the Western Auto store our whole family was involved with the day-to-day operation of the store. At age twelve, alongside family members, I would clean the store wait on customers, make deliveries, change tires, assemble merchandise, and manage transactions. My father's shrewd intuition, dedication and hands on management style meant that no matter what the obstacle was, he usually found a solution.

\section{YOU CANNOT JUDGE A BOOK BY ITS COVER}

When I was set to graduate from the University of South Carolina with a Bachelors of Media Arts, my father approached my girl friend and I with a very unusual question. He asked my girlfriend, Suzanne, if she was going to marry me. She said, "If he ever asks me." He turned to me and asked me if I was ever going to ask her. I said yes and then he said "now that the bull is over with, I want you two to come to work for me at the store". He hired me as store manager and my fiancée to be a customer service representative. It was then that my business education actually began.

My father taught me the business through the schools of experience and trial and error. Like any trained business anthropologist, he paid attention to what made people buy and what kept them from buying (Kim et al., 2007; Underhill 1999, 2010). He taught me psychology, anthropology, business history, marketing, merchandising, ethics, and all other areas of the business that he learned through his own business experiences.

\section{MARLBORO MAN}

Bruce, my father, had a unique read on people in the retail industry. This knowledge is part of being a truly good merchant. One problem small retailers face is being able to get vendors to consider them worthy of service. Frito-Lays and Coca-Cola are touted as being providers of outstanding examples of great customer service to retailers. This is only true if the customer is a large chain or a huge customer. The mom and pop businesses that made them what they are today are completely ignored Vendors often treated our little store in our little town as if we were just a bother. It would not change until we became their most valuable customer.

Our Western Auto Store sold cigarettes at exactly what we paid for them. When we started out we sold three packs of premium brands like Winston and Marlboro for only $80 \phi$. We sold a lot of them and received rebates from the vendors according to our contracts. One day the Phillip Morris representative informed my father that they had raised the number of cartons of Marlboros we had to sell in order to receive a rebate check. Despite regularly selling above the new quota, the idea that the bar had been raised ticked my father off. He was so angry he kicked a hole through the wooden checkout stand we had and hauled everything that mentioned Phillip Morris to the back of the store and spray-painted over the names.

Later, when he calmed down, he realized that this change really meant nothing as far as we were concerned and he decided he would talk to the representative the next time he came around. Later, I ran into the representative at another store. When he asked me how things were I told him that Bruce had calmed down and maybe he could talk with him. I did not know it but the 
representative's supervisor was with him that day. When they showed up at the store and the representative introduced his supervisor to my father, he got upset all over again. I asked my father about his reaction later and he explained that if he signed back up with Phillip Morris while the supervisor was there then forever the supervisor would hold it over the representative's head that he had saved the biggest account. However, if he waited until the representative came back alone and signed up then the representative could claim the victory as his own.

\section{R.C. COLA}

Observation is required by management and supervisors to know what activities and logic clients engage in with relation to products as they are used in the real world. Without observation and first-hand knowledge, opportunities for new business and successful new product lines are lost. Assumptions on the part of management personnel who disregard salesmen's knowledge and the client's ability to distribute a product hurt all parties involved.

Shortly after Suzanne and I began working for my father full time, he said that he really wanted to start selling a product he had loved as a boy, R.C. Cola. But the vendors never came to his store. He told me to get in touch with the route salesman so that he could to talk to him about carrying the R.C. brand. Soon after, I ran into the R.C. route salesman at one of the stores in town. I told him we would like to talk to him at Western Auto about selling R.C. Cola. He agreed to stop by on his way out of town; but he never did.

Several months later I encountered a different route salesman in town and told him the same thing. This vendor was new to the route and to R.C., and had not set up new accounts yet but he agreed to stop by the store and see what he could do. Well, he did actually stop by the store and my father worked out a plan for buying in bulk to sell at a lower cost and still make a profit.

The salesman told him that we would have to buy 300 cases of two liters, and that each week we would have to buy enough two liters to build back up to 300 cases and, if we did, we could sell them at $69 \phi$ each. My father told him to set him up. Then my father asked him what was the least we could sell canned drinks for. The salesman told him we would have to buy 300 cases of those as well and buy back up to 300 cases each week and then we could sell a six pack for about $\$ 1$. My father told him to go ahead.

The route salesman brought in those cases of soft drink and we built a display and put up signs and began selling the soft drinks. Meanwhile, back at the R.C. warehouse, the route salesman was chewed out by his district manager because he thought they were going to have to eventually buy back all those drinks. The district manager told his salesman that when they did finally buy them back, the total cost was going to come out of his commission.

Meanwhile my father loved to sell. Everyone that came into the store was told about the R.C. price. We sold out of all the R.C. drinks in less than two days. That next week the route salesman came to the store with his district manager. When the R.C. salesman came into the store he looked like he had lost his last friend. He was dragging lower than the ears on a Bassett Hound. The first words out of the district manager's mouth were; "Where are all my drinks?" I told him; "We sold them!" He said; "Well what about the drinks in the back room, why aren't they out here?" I told him that we did not put anything in the back room. I went on to tell him that my father Bruce, was upset with R.C. because we ran out of drinks in less than two days and we did not know how to get in touch with them to get more drinks.

My father made it plain with this district manager that we would continue to sell the product as long as the same salesman was on the route and that the district manager left the salesman 
alone. By the time Bruce was finished, the district manager had a change of heart and apologized to the route salesman and then arranged for us to get a brand new R.C. drink machine. Furthermore, they would pay to install an outdoor outlet for the machine.

\section{COCA COLA}

One lesson that I learned while managing the Western Auto Store was that you sometimes have to take a hard line with a vendor and that, when you could not care less if you did business with someone, you were bargaining from a position of strength, an observation that is along with those professional business anthropologists observed (Kim et al., 2007). Coca Cola taught me this. We had a coke machine inside the store that was broken more often than it worked. I constantly had to get the keys to get someone a drink they had paid for. I would call and tell Coca Cola that the machine was broken and they would send someone out several days or even several weeks later to fix it. Then it would be broken again. In the mean time R.C. had given us a machine that worked great.

It was a huge outdoor machine that dispensed bottles instead of cans and R.C. paid to install an outdoor outlet and they paid us a fee for the electricity. Finally I got fed up with Coke and took all the drinks out of the coke machine and just kept some in the refrigerator. I called Coke and told them to pick up their machine. There was no real concern on their part. The Coke route salesman came in and I told him that we would not be buying any more products from him. $\mathrm{He}$ asked me why and I told him that their service was terrible and that they did not seem concerned at all that they were losing our business. The route salesman got on the phone and talked with his boss and his boss's boss. The next day I got a call from Coca Cola.

The man on the phone was very apologetic. He said that, if we would allow it, they would send a brand new outdoor Coke machine and a brand new outdoor Diet Coke machine. I told him fine, but they could not use R.C.'s outlet. He then said they would send an electrician to install an outlet and that they would pay us a fee for the use of the electricity just like R.C. did. The only stipulation was that the machines had to be closer to the front door than the R.C. machine. At the time I had not studied business anthropology nor had I read the book by Dr. Underhill, however, I still knew that this was a great deal for R.C. Most people that purchased drinks came from the garage area of the store, not from the front door. This meant that potential soft drink customers would have to walk by the R.C. machine which offered larger drinks in bottles for less than Coke was selling smaller drinks in cans. R.C. cleaned up on this deal.

\section{SECOND GENERATION of BUSINESS}

At 10:10 AM on 12 May 1987 all of my family business stories came to an end. On that morning, my father Robert Bruce McClendon Jr. died at age 52 of a dissecting aneurism of the aorta. As he lay dying his words were not on dying, but on making sure we got the store open. Shortly after, we closed the store my father established for good and I decided to return to school for a business degree. I went to a small college in South Carolina and it was there that I met a business anthropologist who introduced to Dr. Underhill's work and Business Anthropology to me. After graduating I formed my own business consulting firm, McClendon Enterprises where I continue to the knowledge obtained through my personal experience and education.

Although I had accumulated business knowledge and experiences under my father's training and through working at my family business and other firms, I felt my knowledge was not good 
enough to help others in need. Recently, I decided to return to school and work towards an M.B.A. My professor who introduced business anthropology to me has encouraged me to continue past the M.B.A. and pursue a Ph. D. in business anthropology, which I intend to do as I do believe a good business anthropologist can really help a lot of small family business owners for better operations and profitability.

\section{SUMMARY AND CONCLUSIONS}

Anthropology teaches us how to better understand others by certain means, such as participant observations and life story approach, while more specifically business anthropology leads us to better understand business operations through our understanding of people and culture (Gesteland, 2002). Many successful business people apply business anthropology in everyday business operations regardless of whether they recognize it or not. I have learned through the study of business anthropology that every business owner is dying to tell a story if someone will only listen. There is a reason why some retail stores succeed while others fail. Is it just bad management or poor cash flow that kills a business, or are there other factors at play?

Large corporations have utilized anthropologists to study their customers and how workers manu-facture products. Business anthropologists are hired to help companies understand cultures in other countries, and they help different corporate "cultures" or departments understand each other, as well (Jordan, 1999; Mariampolski, 2005). For small business firms the cost to hire a business anthropologist for help in business operations might be too high. Therefore I will suggest that small family run business owners should learn some basic business anthropological theories and skills, and use them in practices. I suggest that business anthropologists should create and run a training center for small businesses.

It is important to study customers and employees to know what motivates them and why. It is important to know what trends will continue and which ones will soon no longer be an influence on shopping decisions. It is also important for the potential business owner to take the anthropology magnifying glass and take a close look at themselves to learn what motivates them to go into a business and what they want to achieve with the business. Performing ethnographic research and listening to retail stories we may learn something about motivation and consumer behavior. Retail business managers can de perform better in daily operations and increase profitability. It is hoped that a careful study of business anthropology will help us learn how to improve customer service and increase marketing knowledge.

Throughout my life in business I have found that business owners must wear many hats. A good business person must be in tune with their customers and predict trends early on to take advantage of the trends. Successful models of how businesses can profit from the data that is available to them through modern technology include Point of Sale (P.O.S.) terminals and security camera data (Underhill, 2010, 1999). It is true that business anthropologists can make unique contributions.

\section{Acknowledgement}

The author sincerely thanks the editors and the reviewers of IJBA for their insightful comments and constructive suggestions to the development of this article. Special thanks to Daisy Rojas for her professional editing of the paper. 


\section{REFERENCES}

Bronitsky, Gordon (2010). Creating Spaces Where Things Happen: The Life Story of a Business Anthropologist. International Journal of Business Anthropology, 1(1): 111-117.

Chang, Heewon (2008). Autoethnography as Method. Walnut Creek, CA: Left Coast Press.

Dossa, Parin A. (1994). Critical anthropology and life stories: Case study of elderly Ismaili Canadians. Journal of Cross-Cultural Gerontology. 9(3): 335-354.

Gesteland, R.R.( 2002). Cross-Cultural Business Behavior: Marketing, Negotiating, Sourcing and Managing Across Cultures. Copenhagen: Copenhagen Business School Press.

Jordan, A. (2003). Business Anthropology. Prospect Heights, Il: Waveland Press.

Jordan, A. (1999). An Anthropological Approach to the Study of Organizational Change: The Move to Self-Managed Work Teams. Practicing Anthropology, 21(4): 14- 19.

Jones, Andrew M. (2005). The Elementary Structures of the Family Firm: An Anthropological Perspective. Human Organization, 64(3): 276-285.

Kim, Youn-Kyung, Judith Cardona Forney, and Pauline Sullivan (2007). Experiential Retailing: Concepts and Strategies that Sell. New York: Fairchild Publications.

Mariampolski, H. (2005). Ethnography for Marketers: A Guide to Consumer Immersion. Newbury Park, CA: Sage Publications.

Poutziouris, Panikkos Zata, Kosmas X. Smyrnios, and Sabine B. Klein (Eds.) (2006). Handbook of Research on Family Business. Northampton, MA: Edward Elgar Publishing, Inc.

Steward, Alex (2003). Help One Another, Use One Another: Toward an Anthropology of Family Business. Entrepreneurship Theory and Practice, 27(4): 383-396.

Tian, Robert. G. Michale Lillis, and Alfons H. van Marrewijk (2010). General Business Anthropology. Miami, FL: North American: Business Press.

Underhill, Paco (2010). What Women Want: The Global Marketplace Turns Female Friendly. New York, NY: Simon \& Schuster.

Underhill, Paco (1999). Why We Buy: The Science of Shopping. New York, NY: Simon \& Schuster, Inc. 